ROCZNIKI NAUK SPOŁECZNYCH

Tom 13(49), numer $1-2021$

DOI: https://doi.org/10.18290/rns21491.10

ROBERT SZWED

\title{
KRYZYS INFORMACJI \\ W ZMEDIATYZOWANEJ SFERZE PUBLICZNEJ - OD MEDIÓW TRADYCYJNYCH DO HYBRYDOWYCH PLATFORM KOMUNIKACYJNYCH
}

\section{WPROWADZENIE}

W dobrze funkcjonujących demokracjach fundamentalną rolę odgrywa autonomiczna sfera publiczna, w której wolni i równi obywatele realizują zasadę suwerenności zagwarantowaną prawem i utrwaloną praktyką (Hułas, 2019). Jürgen Habermas, który jako pierwszy sferę publiczną skonceptualizował, widział ją właśnie jako przestrzeń osób prywatnych, które tworząc samoświadomą publiczność, wysuwają wobec władzy postulaty roszczeniowe jako owoc racjonalnej deliberacji. $\mathrm{Z}$ tak rozumianej sfery publicznej wyłania się opinia publiczna jako funkcja niewymuszonej i wolnej komunikacji ukierunkowanej na działania zbiorowe i porozumienie (Habermas, 2007).

Dla funkcjonowania tak rozumianej sfery publicznej niezbędnych jest kilka warunków: 1) zagwarantowane są prawa wolności wypowiedzi dla obywateli; 2) rzeczy, o których dyskutują, są jawne; 3) uczestnicy procesu komunikacji są w stanie je zrozumieć, krytycznie ocenić różne racje, a następnie we współpracy wejść w dialog i dojść do konsensusu; 4) istnieją środki przekazu, poprzez które i dzięki którym obywatelska debata się toczy.

$\mathrm{Z}$ perspektywy funkcjonowania demokracji kluczowe wydaje się pytanie, czy - z jednej strony - system społeczno-polityczny wspiera ideę odpowiedzialnego, samoświadomego, autonomicznego i kompetentnego społeczeństwa, a z drugiej - czy środki przekazu stanowią realną platformę komunikacji między obywatelami i obywateli z władzą.

Dr hab. RoBert Szwed - Katedra Kultury Medialnej, Instytut Dziennikarstwa i Zarządzania, Wydział Nauk Społecznych, Katolicki Uniwersytet Lubelski Jana Pawła II, Al. Racławickie 14, 20-950 Lublin; e-mail: szwed @ kul.pl; ORCID: https://orcid.org/0000-0002-2700-0292. 
W niniejszym artykule skupimy swoją uwagę na odpowiedzi na pytanie o kondycję informacji w zmediatyzowanej sferze publicznej i dziennikarstwa w budowaniu przestrzeni komunikacyjnej społeczeństw, których członkowie lepiej lub gorzej potrafią ocenić jakość docierających do nich informacji. W tym celu, w pierwszej części artykułu, ukazane zostaną słabości tradycyjnego dziennikarstwa. W drugiej części zwrócimy się w kierunku konsumentów i prosumentów treści medialnych, których rozumienie przekazów, wykorzystanie, aktywność i zaangażowanie zostaną ocenione przez pryzmat zasad budowania rzetelnych i obiektywnych informacji. Część trzecia artykułu umieszcza informacje publikowane w przestrzeni internetowej, w kontekście logiki biznesu platform cyfrowych, który charakteryzują trzy pojęcia: datyfikacji, komodyfikacji i zarządzania uwagą.

\section{TRADYCYJNE DZIENNIKARSTWO - OD DOSTARCZANIA INFORMACJI DO PRODUKCJI NEWSÓW}

Zgodnie z klasycznym modelem informacji dziennikarskiej jest ona funkcją dwóch elementów: 1) faktów i działań, które nieustannie „się dzieją” w świecie, oraz 2) dziennikarzy, którzy owe zdarzenia dostrzegają, a następnie relacjonują. Taką wizję dziennikarstwa prezentowali w pierwszej połowie XX wieku Robert E. Park, socjolog i dziennikarz, oraz Wilbur Schramm - „ojciec” nauki o komunikowaniu. Park w swoim artykule News as a form of knowledge porównywał funkcje, jakie pełni news dla odbiorców, do funkcji zmysłu postrzegania, jaką pełni on dla jednostki: news ,nie tyle informuje, ile orientuje publiczność, dostarcza wiadomości na temat tego, co się aktualnie dzieje”. Jego oddziaływanie nie jest przy tym rezultatem ,,podejmowanej przez reportera próby interpretacji wydarzeń, [chyba że] w zakresie, w jakim czyni to newsy zrozumiałymi i interesującymi" (Park, 1940, s. 677). Dziennikarz nie tworzy zatem wiadomości, lecz je relacjonuje, nie wymyśla, ale odtwarza i zgodnie $\mathrm{z}$ „obiektywnymi” kryteriami rzetelności i ważności wydarzeń, spośród masy faktów wybiera takie, które danego dnia kryteria istotności spełniają w największym stopniu. W obliczu siły „nagich faktów” staje bezbronny w tym sensie, że nie pozostaje mu nic innego, jak je upowszechnić po to - jak pisał Park - aby zorientować publiczność, o co właściwie chodzi.

Tak rozumiany model tworzenia informacji jest ideą, drogowskazem i jeszcze przed internetową rewolucją i pojawieniem się nowych platform komunikacyjnych został poddany krytyce. Każdy z jego elementów: proces budowania 
informacji, ich upowszechnianie i odbiór stały się przedmiotem intensywnych badań i bardzo szybko dostrzeżono, że nie jest on ani transparentny, ani prosty (Szwed, 2009).

Na początku okazało się - zgodnie z koncepcją „gatekeeperów” zaproponowaną przez socjologa Kurta Lewina - że zdolność do rozpowszechniania różnorodnych informacji, zjawisk czy zachowań jest funkcją zdolności ich przepływu przez kanały transferowe (Lewin, 1947). Aby dotrzeć do publiczności, każdy element musi przejść przez umieszczone w nich „bramy”, którymi zarządzają jednostki lub grupy ludzi, podejmujących decyzje, jaki element przepuścić, a jaki zatrzymać. W odniesieniu do prasy koncepcję selekcji informacji zastosował David M. White, który w swoich badaniach dowodził, że proces selekcji wydarzeń jest subiektywny, oparty na doświadczeniach i przekonaniach osobistych gatekeepera. Jest to proces, w którym dziennikarz kieruje się uprzednio posiadanymi postawami i oczekiwaniami wobec rzeczywistości, nie zaś obiektywną wartością informacji (White, 1950).

W świetle rewolucji technologicznej, pojawienia się nowych formatów informowania opinii publicznej teoria gatekeeperów straciła na wartości, bowiem współcześnie nie ma sposobu na efektywne blokowanie określonych, niewygodnych czy „niewłaściwych” wiadomości. Dlatego Bruce A. Williams i Michael X. Delli Carpinii w Unchained reaction. The collapse of media gatekeeping and the Clinton-Lewinsky scandal stwierdzili, że obecnie mamy do czynienia z eliminacją tradycyjnej roli gatekeepera, jaką zajmowała dotychczas tzw. prasa głównego nurtu. W obliczu nowego, spluralizowanego środowiska mediów elektronicznych, Internetu i prasy, wizja jakichkolwiek bram czy grodzi jest anachroniczna. A zatem skoro ,nie ma bram, nie może też być gatekeeperów" (Williams, Delli Carpinii, 2000, s. 62).

Kolejną ważną grupą teorii, które poddawały w wątpliwość aktualność klasycznego modelu informacji, były teorie związane $\mathrm{z}$ wartością informacji. Zgodnie z nimi zadawano pytanie o to, jakie właściwie informacje są przez media w sferze publicznej rozpowszechniane i jakie są „elementy, bez których szanujące się doniesienie informacyjne nie może się obejść" (Boyd, 2006, s. 25). Dla Waltera Lippmanna - jeszcze przed II wojną światową - aby jakieś zdarzenie mogło zostać uznane za newsa, powinno mieć w sobie coś, na czym opowieść dziennikarską można by oprzeć: „Coś szczególnego musi się wydarzyć w niecodzienny sposób. Może to być bankructwo, pożar, wypadek, napad, strajk, aresztowanie, wprowadzenie nowego aktu prawnego, przemówienie, głosowanie, spotkanie, opinia znanego obywatela, artykuł redakcyjny w gazecie, wyprzedaż, zmiana cen, propozycja wybudowania mostu [...]" (Lippmann, 
1997, s. 215). Wymieniając również inne, konkretne sytuacje i problemy, które czynią zdarzenie w jakimś aspekcie warte odnotowania w prasie (np. warunki pracy, szanse edukacyjne czy bezrobocie), zauważa, że nie zawsze decyzje o publikacji materiału są oczywiste $\mathrm{i}$ w wielu sytuacjach pojawia się wątpliwości co do funkcji, jaką news ma pełnić (funkcja propagandowa, zabezpieczenia interesu właściciela). Badania empiryczne potwierdziły ustalenia Lippmanna. Wynika z nich, że istnieją czynniki, które zwiększają prawdopodobieństwo publikacji danego materiału.

Do klasycznych $\mathrm{w}$ tym zakresie należą badania przeprowadzone na początku lat 60. XX wieku przez Johana Galtunga i Marie H. Ruge (Galtung, Ruge, 1965, s. 45), a także badania Roberta H. Bohle'a, Sophii Peterson czy Geralda Stone'a, Barbary Hartung i Dwighta Jensena (Bohl i in., 1987). Do czynników decydujących o ukazaniu się określonej informacji Andrew Boyd zaliczył bliskość (społeczne znaczenie wydarzenia), istotność, aktualność, zainteresowanie (,informacja zapiera dech w piersiach”), dramatyzm i rozrywkę (Boyd, 2006). Z kolei Tony Harcup i Deirdre O'Neill (Harcup, O'Neil, 2001, s. 279) zauważają, że dobra informacja powinna dotyczyć elit władzy (jednostek, organizacji i instytucji), osób powszechnie znanych (celebrities), powinna bawić, zaskakiwać, straszyć i smucić (bad news), podnosić na duchu (good news), dotyczyć dużej liczby osób, zjawisk powszechnie akceptowanych jako istotne, które wcześniej pojawiły się w doniesieniach informacyjnych i promujących linię programową nadawcy (newspaper agenda). Kryterium decydującym o wyborze tej lub innej informacji nie jest zatem jej istotność, ważność, lecz raczej takie czynniki, które zwiększą szansę ich dostrzeżenia przez publiczność.

Ograniczenia dotyczące publikacji informacji nie wynikają jednak tylko z dziennikarskich przekonań, ale są funkcją interesu organizacji medialnych lub korporacji będących właścicielami mediów. Zakłada się, że dziennikarz jest częścią systemu, którego celem jest maksymalizacja zysku, interesu nadawcy lub jego właścicieli, nie zaś interes czytelników, opinii publicznej. Ten typ postawy w polityce doskonale obrazuje wypowiedź prezesa Prawa i Sprawiedliwości, Jarosława Kaczyńskiego, który jeszcze w 2006 roku stwierdzał:

Wolność prasy to również wolność dziennikarza. Bo jeśli to jest tylko wolność wydawców, właścicieli, to jest wolność garstki ludzi, którzy niekoniecznie muszą się kierować interesem społecznym. Jest bardziej prawdopodobne, że ten interes społeczny będzie zachowany, jeśli będzie w ręku tysięcy ludzi, bo są tysiące dziennikarzy w Polsce, niż jeśli będzie w ręku pani Rapaczyńskiej [prezes Agory, wydawcy „Gazety Wyborczej”], pana Tyczyńskiego [prezes Radia RMF FM], pana Gaudena 
[prezes wydawnictwa wydającego „Rzeczpospolitą” i naczelny redaktor tej gazety] czy Króla [właściciel i redaktor naczelny „Wprost”]. Na palcach dwóch rąk można tych wszystkich najważniejszych policzyć. Oni decydują o kształcie mediów i zakresie wolności. [Jakiś czas potem, wyjaśniając, dodał] Jeśli mówiłem o braku wolności w polskich mediach, to mówiłem o sytuacji polskiego dziennikarza. W moim przekonaniu w bardzo wielu przypadkach sytuacji niedobrej, która skłania do różnego rodzaju kompromisów, do pisania nie tego, co się sądzi (Jarosław Kaczyński: wydawcy sq winni, „Gazeta Wyborcza”, 06/03/2006, s. 4).

Mając taką właśnie wizję mediów, Jarosław Kaczyński przedsięwziął właściwe - jego zdaniem - środki „gwarantujące wolność dziennikarzy”, gdy sam stał się ich dysponentem. Wizja ta wynika z przekonania, że reporterzy są zmuszeni/można ich zmusić do podporządkowania się instrukcjom właściciela, wydawcy.

Wpływ właścicielski na treści udostępniane w mediach został udokumentowany w badaniach jeszcze w 1955 roku przez Warrena Breeda, gdy stwierdził on, że „politykę informacyjną ustalają wydawcy i zgodnie z nią zwykle podążają pracownicy redakcji” (Breed, 1955, s. 326). Z kolei zgodnie z modelem propagandowym Edwarda S. Hermana i Normana Chomsky'ego (Herman, Chomsky, 1988) media są częścią dominującego w systemie układu biznesowo-ideologiczno-politycznego i reprezentują interesy najpotężniejszej części społeczeństwa. W celu obrony istniejącego konsensusu selekcjonują i kształtują wiadomości w taki sposób, aby wspierały one i legitymizowały istniejący stan rzeczy. „W świecie skoncentrowanego bogactwa i zasadniczych konfliktów interesu klasowego, w celu wypełnienia tej roli [mediów] wymagana jest propaganda systemowa" (Herman, Chomsky, 1988, s. 2). Owa propaganda buduje sens zdarzeń i jest narratorem rzeczywistości. Współcześnie również np. David K. Demers dowodził, że w zależności od typu własności i struktury organizacyjnej (korporacyjna ze skomplikowaną strukturą zarządzania vs zarządzana przez jednego lub niewielką grupę właścicieli, z prostą organizacją) dziennik jest odpowiednio bardziej lub mniej krytyczny wobec władzy (Demers, 1998). Krytycy takiego właśnie modelu zauważają jednak, że istnieje wiele przykładów, które dowodzą, że „układ”, „system” nie jest wszechmocny: „Rząd i dominujące w mediach elity nie poradziły sobie z syndromem wietnamskim, publiczną wrogością wobec bezpośredniej interwencji USA, zaangażowaniem w obalenie i destabilizację obcych rządów" (Schudson, 2002).

Klasyczną teorię wartości informacji w sferze publicznej podważają również różnego rodzaju koncepcje wpływu zewnętrznego. Zgodnie z nimi istotnymi 
czynnikami odpowiadającymi za kształt informacji są reklamodawcy, specjaliści public relations oraz odbiorcy, opinia publiczna. Liczne badania wskazują, że w wielu sytuacjach w sposób bezpośredni to one właśnie decydują o zawartości wydań informacyjnych w prasie, radiu, telewizji i Internecie. Tę krytykę doskonale uchwycił Ryszard Kapuściński, który zauważył, że

[...] informacja jest świetnym, przynoszącym wielkie zyski towarem, a jej rozpowszechnianie i sprzedaż - krociowym interesem. Dawniej wartość informacji wiązano z takimi pojęciami, jak szukanie i przekazywanie prawdy, albo też widziano w niej ważny instrument walki politycznej o wpływy i władzę... Teraz najważniejsze jest co innego - wartość informacji mierzy się jej atrakcyjnością. Informacja musi się przede wszystkim dobrze sprzedawać! Najprawdziwsza informacja nie ma żadnej wartości, jeżeli nie jest atrakcyjna i nie przyciąga coraz bardziej zresztą znużonej i rozkapryszonej publiczności (Kapuściński, 1998).

Informacje mają zatem przyciągać audytoria, a dzięki temu zainteresować potencjalnych inwestorów i zachęcać reklamodawców. Zdaniem Charlesa Bantza taki związek między nakładem i oglądalnością a ekonomiczną opłacalnością prowadzi do tego, że wydawcy mogą powstrzymywać się przed upowszechnianiem informacji kontrowersyjnych z punktu widzenia interesu sponsora-ogłoszeniodawcy i nieatrakcyjnych z punktu widzenia audytorium (Bantz i in., 1980).

Podsumowując badania nad informacją i klasycznym, ,przedinternetowym dziennikarstwem" okazuje się, że proces produkcji informacji zawsze był procesem złożonym, o którego przebiegu w różnym stopniu, w różnych sytuacjach decydowały różne czynniki. Nie jest on po prostu obiektywnym relacjonowaniem najistotniejszych wydarzeń, ale zależy przynajmniej od kilku czynników: indywidualnych przekonań dziennikarzy (w tym sensie ciągle pełnią oni funkcję gatekeeperów), potencjalnej atrakcyjności materiału z perspektywy publiczności, wydawców i reklamodawców, a na jego ostateczny kształt mają również wpływ spin doktorzy i różnego rodzaju pracownicy public relations odpowiadający za komunikację instytucji i partii politycznych (Szwed, 2009).

Jest to niebezpieczne z perspektywy interesu publicznego zarówno wówczas, gdy dysponentem mediów jest środowisko polityczne o słabo wykształconej kulturze politycznej, jak i wtedy, gdy o strukturze wydań informacyjnych decydują dziennikarze świadomi swojego zobowiązania do zabezpieczenia interesu pracodawcy. 
Czy sfera publiczna i dziennikarstwo zmieniły się wraz z rewolucją technologiczną, rozwojem Internetu i nowymi możliwościami komunikacyjnymi? Czy „nowa”, zmediatyzowana sfera publiczna przypomina - jak pisał Slavko Splichal - „sieci komunikacyjne [...] przestrzenie nowoczesnego miasta, parki i ulice, teatry, puby i kawiarnie, gdzie mieszają się ze sobą, gromadzą i komunikują przedstawiciele wszystkich klas i grup społecznych", a dostęp do tych sieci komunikacyjnych ,jest powszechny, nie determinowany przez rynek, ani przez państwo, a kanały komunikacyjne są wspólną własnością [...] przedmiotem regulacji i publicznej odpowiedzialności” (Splichal, 1999, s. 296)?

\section{ROZWÓJ DZIENNIKARSTWA BLOGOWEGO - OD KONSUMENTÓW DO PROSUMENTÓW INFORMACJI}

Wartość wspomnianej wizji Splichala tkwi w jej wymiarze normatywnym: jest zaledwie idealistyczną wizją, która nie była aktualna ani w mediach tradycyjnych, ani w zdominowanym przez Internet hybrydowym systemie medialnym.

Pojawienie się w latach dziewięćdziesiątych XX wieku nowych technologii opartych na cyfrowym transferze danych w Internecie zwiastowało erę nieograniczonego niemal dostępu do informacji, a co za tym idzie - jak zakładano - zwiększenia wiedzy i kompetencji obywateli. Internet 1.0 dawał możliwość czytania, oglądania, słuchania i przeglądania zawartości online w skali dotychczas nieznanej. Cóż z tego, jeśli zgodnie z hipotezą luki wiedzy (knowledge gap), sformułowaną w roku 1970 przez Phillipa J. Tichenora, George'a A. Donohue i Clarice N. Olien, segmenty populacji o wyższym statusie społeczno-ekonomicznym efektywniej niż segmenty o niższym statusie potrafiły wykorzystać informacje płynące $\mathrm{z}$ mediów, tak że w rezultacie luka w wiedzy między różnymi segmentami społecznymi raczej rosła, niż malała (Tichenor, Donohue, Olien, 1970)? Znalazło to potwierdzenie w kolejnych badaniach (Gaziano 1995; Hwang, Jeong, 2009; Viswanath, Finnegan, 1996). Nowe nadzieje przyniósł Internet 2.0, który oferował nie tylko możliwość konsumowania, lecz także produkowania własnych treści (Ritzer, 2011). Dla opisania zmieniającej się roli publiczności stworzono nowy termin - „prosumenci”, odnoszący się do osób, które jednocześnie produkują i konsumują (treści medialne). Dzięki nowym aplikacjom internetowym, takim jak YouTube (uruchomiony w roku 2005), Facebook (2006) czy Twitter (2008), każdy ich użytkownik może aktywnie uczestniczyć w procesie budowania i obiegu informacji w zmediatyzowanej internetowej sferze publicznej. Pojawienie się 
takich aplikacji - jak zauważył Paul Andrews - może prowadzić do ustanowienia nowego paradygmatu dziennikarstwa blogowego, które obejmie nie tylko tradycyjne, scentralizowane, odgórne, jednostronne publikatory, lecz także wielostronne, powstałe w rezultacie sprzężenia zwrotnego, komunikaty w sieci (Andrews, 2003).

Badania w zakresie zmian w kompetencjach i wiedzy konsumentów i prosumentów w Internecie 2.0 sugerują, że hipoteza luki w wiedzy między różnymi segmentami społecznymi jest wciąż aktualna (Kwak, 1999; Gaziano, 2017). Co prawda, jej znaczenie zależy od zaangażowania użytkowników, ich motywacji, intensywności korzystania z mediów, jednak ostatecznie mamy do czynienia z „przepaścią cyfrową” nie tylko między tymi, którzy mają lub nie mają dostępu do Internetu, ale również między tymi, którzy potrafią korzystać z cyfrowych zasobów, i tymi, którzy tego nie potrafią (Wei, Hindman, 2011).

Abstrahując od kompetencji medialnych obywateli, Internet zapowiadał możliwość swobodnego wyrażania opinii i zaangażowania obywateli w życie publiczne (Negroponte, 1998, s. 288; Rheingold, 1993), miał się stać przestrzenią organizowania się społeczeństwa i wywierania wpływu na politykę (Bowen, 1996), sferą, w której nieustająco odbywać się będą „elektroniczne plebiscyty", sondaże, referenda i głosowania (Abramson, Arterton, Orren, 1988). Rozwój zmediatyzowanej sfery publicznej prowadził entuzjastycznie nastawionych badaczy np. do wizji „klawiaturowej demokracji” (Grossman, 1995), w której urzeczywistni się wizja reprezentatywności, równości i powszechnego dostępu do danych.

Bardzo szybko okazało się jednak, że Internet jako nowa przestrzeń aktywności publicznej tworzy iluzję otwartości i równości, a badania, prowadzone jeszcze w latach 90., dowodziły, że internetowa przestrzeń jest w istocie ekskluzywna, elitystyczna (Pavlik, 1994), w której dyskusje nie są prowadzone przez obywateli, ale przez elity (Jankowski, van Selm, 2000). Nadto w XXI wieku stała się siedliskiem internetowych trolli (Brodshaw, Howard, 2017; Szwed, 2016), przestrzenią inwigilacji i dezinformacji eksploatowaną przez różnego rodzaju grupy ekstremistyczne (Gerstenfeld, Grant, Chiang, 2003), źródłem przemocy (Pasquale, 2018) i wreszcie bronią wykorzystywaną przez niedemokratyczne reżimy, cyberprzestępców i cyberterrorystów (Cohen-Almagor, 2015).

W ten sposób niedoskonałość medialnej sfery publicznej w mediach tradycyjnych została wzmocniona alternatywną, cyfrową przestrzenią zorganizowanego zarządzania uwagą, nadużyć, fake newsów, teorii spiskowych i idei, w których postprawda skutecznie rywalizuje z prawdą. 
Nowa infrastruktura komunikacyjna nie przyniosła jednak zmian w funkcjach pełnionych przez media. Media niezmiennie są przestrzenią rozrywki, ale mają również informować, kontrolować rządzących, być platformą dyskusji i edukować (Christians i in., 2009). Nie znikły też słabości, z którymi dziennikarstwo i sfera publiczna borykały się od początku: stronniczości dziennikarzy i selektywności w doborze materiałów, skupianiu swojej uwagi na niektórych tylko tematach, wykorzystywaniu „,sieci wiadomości” w zdobywaniu informacji w wyselekcjonowanych wcześniej przestrzeniach (sądy, policja, szpitale), wreszcie podatności na naciski w ramach redakcji i presji wywieranej przez interesariuszy zewnętrznych.

Zmieniła się natomiast szybkość przekazywania informacji, potencjalny do nich dostęp, a nadto znikły ograniczenia w możliwości upowszechniania dowolnych faktów. Pojawiły się nowe źródła obywatelskiej informacji, dotychczas w niewielkim stopniu obecne w mediach tradycyjnych, które mają tę nad nimi przewagę, że obejmują swoim zasięgiem również przestrzenie, których media swym zasięgiem nie są w stanie objąć.

Dlatego w systemie informacyjnym 24/7 „nieprofesjonalne”, ale skuteczne, szybkie, wygodne i tanie źródła online stanowią konkurencję i inspirację dla dziennikarzy, którzy wykorzystują je w swojej pracy, budując własne opowieści-newsy (Lecheler, Kruikemeier, 2016). Dzięki „obywatelskiej sieci wiadomości" widzimy prezydentów szusujących na nartach, ukryte spotkania wpływowych polityków i relacje z demonstracji, których nie zarejestrowały kamery mediów tradycyjnych. Takie informacje są czasem kluczowe dla zrozumienia tego, co się aktualnie dzieje, choć z drugiej strony - trudne do weryfikacji. Publikując je, redakcje narażają się na uzasadnioną krytykę z perspektywy warsztatowej, co bywa „rozgrzeszane” ze względu na presję czasu. Przyczynia się to jednak do pogłębienia kryzysu dziennikarstwa, od którego oczekuje się sprawdzonych i wiarygodnych informacji. Badania empiryczne w tym zakresie wskazują jednak, że media relatywnie rzadko korzystają z takich właśnie „nieprofesjonalnych” źródeł informacji (Thorsen, Jackson, 2018; Vliegenthart, Boukes, 2018; von Nordheim i in., 2018; Johnson i in., 2018). Okazuje się bowiem, że ich weryfikacja, filtrowanie jest znacznie bardziej pracochłonne niż opieranie się na tradycyjnych „sieciach wiadomości”, które stanowią np. politycy, sędziowie i prokuratorzy, policjanci czy lekarze. Dlatego zazwyczaj są one bodźcem dla pogłębionych, profesjonalnych działań dziennikarzy.

Mimo to, że tradycyjni wydawcy dominują w medialnej sferze publicznej, to - choćby ze względu na mnogość źródeł informacji - muszą się liczyć z tym, że funkcje dotychczas pełnione przez nich, w tym funkcję informacyjną i kontrolną, 
przejęły częściowo inne organizacje, amatorsko-profesjonalne - na świecie np. WikiLeaks (Wahl-Jorgensen), a w Polsce bracia Sekielscy, „Krytyka polityczna” czy oko.press. Obecność instytucji niekojarzonych dotychczas z tradycyjnymi mediami z pewnością przyczynia się do większego pluralizmu w sferze publicznej, choć zmusza je do nieustannego monitorowania zmieniających się warunków prowadzenia działalności medialnej: od procesu produkcji informacji, przez dystrybucję, aż po nowe wzory konsumpcji. Internet i cyfrowa aktywność obywateli prowadzi do zacierania się granic w sferze publicznej między dziennikarstwem a paradziennikarstwem, dziennikarstwem blogowym, między obiektywnością i wiarygodnością a woluntaryzmem. W ten sposób przeciętny użytkownik mediów obok poważnych analiz dziennikarskich, artykułów śledczych znajduje artykuły sponsorowane i fake newsy, i ostatecznie sam musi dokonać oceny ich rzetelności. Prowadzi to do fragmentaryzacji publiczności, polaryzacji i podziałów opartych na dość przypadkowych treściach, co utrudnia osiąganie consensusu społecznego. Oznacza to, że funkcję informacyjną i edukacyjną w coraz mniejszym stopniu wypełniają zarówno tradycyjne, jak i nowe media.

\section{MEDIA PLATFORMOWE - MIĘDZY DOSTARCZANIEM INFORMACJI A KOMODYFIKACJĄ}

Dla zrozumienia przyczyn kryzysu informacji w zmediatyzowanej sferze publicznej należy umieścić system medialny w kontekście nowej infrastruktury komunikacyjnej, której działalność w wymiarze ekonomicznym jest funkcją datyfikacji (Mayer-Schönberger, Ramge, 2018; Murray i in., 2020; van Dijck i in., 2018).

Jak w 2017 roku doniósł The Economist, najbardziej cenionym zasobem naszych czasów ,już nie jest ropa naftowa, lecz dane"1. Dlatego badacze i analitycy mediów skupiają uwagę na - generującej różnego rodzaju informacje - złożonej, algorytmiczno-obliczeniowej infrastrukturze Internetu, której funkcjonowanie jest nieprzejrzyste dla przeciętnych użytkowników mediów elektronicznych. Jej celem jest nie tylko maksymalizacja zysku, lecz także ustanowienie obywateli źródłem informacji w komercyjnym projekcie gromadzenia danych służących do przewidywania naszych zachowań. W ten sposób, w ciągu zaledwie kilkudziesięciu lat, nadzieje związane z rozwojem Internetu jako nowej sfery publicznej zostały zastąpione obawami i przeko-

\footnotetext{
${ }^{1}$ https://www.economist.com/leaders/2017/05/06/the-worlds-most-valuable-resource-is-no-lo nger-oil-but-data [dostęp: 28.02.2021].
} 
naniem, że odbiega ona od ideału nie mniej, niż XVII- i XVIII-wieczna sfera publiczna opisana przez Habermasa.

Dla zrozumienia kryzysu mediów i sfery publicznej niezbędne jest umieszczenie ich w aktualnym kontekście technologiczno-biznesowym, w którym głównymi graczami stały się - ustanawiające architekturę zmediatyzowanej sfery publicznej - platformy cyfrowe pośredniczące w dostarczaniu informacji, łączące jednostki między sobą, a ludzi - z produktami.

Te nowe, cyfrowe architektury, które pozornie przypominają wspomniane przestrzenie nowoczesnego miasta, parki i ulice, teatry, puby i kawiarnie, są $\mathrm{w}$ istocie cyfrowymi centrami handlowymi, które - zgodnie z założeniami merchandisingu - eksponują wybrane produkty, obowiązkowo monitorując zachowania wszystkich swoich klientów. Logiką, na której się opierają, jest ekonomia uwagi, która polega na eksponowaniu przyciągających i angażujących publiczność treści, dostarczanych przez różnych uczestników sfery publicznej: od celebrytów i influencerów do polityków i ekspertów. Choć mierniki oglądalności czy słuchalności od zawsze były kluczowym czynnikiem w ocenie działalności mediów, to platformy cyfrowe uczyniły z clickbaitu nie tylko podstawowy instrument przyciągania uwagi, lecz także miarę ekonomicznej efektywności przekazu.

Zasięg i oddziaływanie firm platformowych trudno przecenić - spośród dziesięciu najpotężniejszych marek w 2020 roku aż sześć (Amazon, Apple, Microsoft, Google, Alibaba i Facebook) jest opartych na biznesie platformowym. Ów biznes dobrze charakteryzują trzy pojęcia: datyfikacja, komodyfikacja i zarządzanie uwagą.

Datyfikacja jest podstawową kategorią opisującą działalność biznesową platform. Polega ona na przekształcaniu w dane wielu aspektów życia użytkowników, których dotychczas nie określono ilościowo i na takim poziomie szczegółowości, jak obecnie. Działania jednostek łączone są z takimi funkcjami platform, jak wyszukiwanie, ocenianie, oglądanie, polubienie, śledzenie i udostępnianie. Pozwala to łączyć podstawowe informacje demograficzne użytkowników ze znacznikami czasu, lokalizacją, zainteresowaniami, nastrojami, transakcjami, procedurami socjalizacji i wieloma innymi zasobami.

Utowarowienie (komodyfikacja) informacji polega na tym, że platformy przekształcają aktywność użytkowników (a także obiekty online i offline, z którymi można ich powiązać) w zbywalne towary. Pozwala to łączyć ogromną ilość gromadzonych i przetwarzanych danych dotyczących preferencji i potrzeb użytkowników ze spersonalizowanymi usługami i reklamami oferowanymi na platformach. 
Zarządzanie uwagą, które przypomina „tradycyjny” gatekeeping, polega natomiast na wyborze dla użytkowników platform odpowiednich tematów, ofert, usług, przedmiotów, które są dla nich dedykowane. Niegdyś to eksperci i profesjonalne instytucje, dziennikarze, kierując się wiedzą i normami zawodowymi, określały np. to, co jest znaczącą informacją. Teraz to platformy cyfrowe wprowadziły selekcję opartą na użytkownikach i algorytmach. Dokonują tego poprzez personalizację treści, która dzięki informacjom płynącym od indywidualnych użytkowników, decyduje o tym, które treści lub opcje użytkownik zobaczy. Algorytmy, za pomocą których odbywa się ta spersonalizowana selekcja, są zwykle chronione tajemnicą handlową, co utrudnia obserwatorom zrozumienie procesu, który wpływa np. na wyniki naszych wyszukiwań w Google. Chociaż spersonalizowana selekcja ma ułatwiać użytkownikom znajdowanie ofert i informacji, które są dla nich najbardziej odpowiednie, to może również prowadzić do fragmentacji społecznej, w której ludzie funkcjonują w ramach oddzielonych od siebie „baniek informacyjnych". Trendy i reputacja (definiowane poprzez klikalność, szerowalność i recenzje) również określają, które treści mają największy impakt w Internecie. Dlatego właśnie wiele platform oferuje listy „wartych przeczytania tematów” na podstawie algorytmicznej identyfikacji popularności. Wreszcie platformy angażują się w moderowanie treści zarówno za pomocą automatycznych filtrów, jak i ludzkiej selekcji. W przypadku mediów społecznościowych taka moderacja często budzi kontrowersje, bowiem platformy usuwają np. ważne treści historyczne lub kulturowe, uznając je za naruszające przepisy dotyczące nagości lub przemocy graficznej.

W ten sposób - napędzane przez dane, a zarządzane przez algorytmy platformy cyfrowe znacząco wpływają na przebieg debaty publicznej i standardy zachowań online, ustanawiają nowe relacje władzy i skutecznie „reorganizują reżimy wartości i gospodarki” (van Dijck i in., 2018, s. 52). Pozostając poza publiczną kontrolą, oddziałują na wszystkie sektory społeczeństwa, budują społeczną wyobraźnię i odpowiadają za przepływ informacji.

Ekonomia uwagi, która zdominowała myślenie w ramach nowych i starych mediów, spowodowała dalsze pogorszenie się standardów dziennikarskich i wzmocnienia niekorzystnych trendów: tabloidyzacji, infotainmentu i produkcji soft newsów, które stały się oczekiwanym formatem informowania. Rysujący się obraz zmediatyzowanej sfery publicznej dopełniają fake newsy, dezinformacja i posprawda, które na spolaryzowanym, populistycznym rynku newsów cieszą się nieustannym zainteresowaniem. 
Czy będące w kryzysie tradycyjne media są skazane na upadek? Dziennikarze uwięzieni w logice clickbaitu, sparaliżowani koniecznością nieustannego przyciągania uwagi, budowania informacji poruszających emocje ujawniają sensacyjne wydarzenia i wykroczenia, które często nimi nie są, prowadząc do dalszego rozczarowania polityką i mediami.

W obecnej sytuacji media i dziennikarze muszą przemyśleć swoją rolę i miejsce na rynku informacji, na którym nie są już monopolistami. Broniąc swojej pozycji, powinni zwrócić się w kierunku zasad bezstronności, obiektywizmu i rzetelności, dzięki czemu odbudują swoją wiarygodność i reputację. Pytanie, które wykracza poza zakres niniejszego artykuł, brzmi: czy tego samego od dziennikarzy oczekują dysponenci mediów tradycyjnych i platformowych oraz konsumenci informacji.

\section{BIBLIOGRAFIA}

Abramson J.B., Arterton F.C., Orren G.R. (1988), The electronic commonwealth: The impact of new media technologies on democratic politics, New York: Basic Books.

Andrews P. (2003), Is blogging journalism? Nieman Reports, nr 57(3), s. 63-65.

Bohle, R.H. (1986), Negativism as news selection predictor, Journalism Quarterly, nr 63, s. 789-796.

Bowen C. (1996), Modem nation: The handbook of grassroots American activism online, New York: Random House.

Boyd A. (2006), Dziennikarstwo radiowo-telewizyjne. Techniki tworzenia programów informacyjnych, Kraków: Wydawnictwo Uniwersytetu Jagiellońskiego.

Breed W. (1995), Social control in the newsroom: A functional analysis, Social Forces, nr 33(4), s. 326-335.

Brodshaw S., Howard P.H. (2017), Troops, trools and troublemakers: A global inventory of organized social media manipulation, Working Paper no. 2017.12.

Christians C.G., Glasser T.L., McQuail D. (red.) (2009), Normative theories of the media: Journalism in democratic societies, Urbana: University of Illinois Press.

Cohen-Almagor R. (2015), Confronting the Internet's dark side: Moral and social responsibility on the free highway, New York: Cambridge University Press.

Demers D.K. (1988), Structural pluralism. Corporate newspaper structure, and news source perceptions: Another test of the editorial vigor hypothesis, Journalism and Mass Communications Quarterly, $\mathrm{nr}$ 75(3), s. 572-592.

Farag D. (2017), From Tweeter to terrorist: Combatting online propaganda when Jihad goes viral, The American Criminal Law Review, nr 54(3), s. 843-883.

Galtung J., Ruge M. (1965), The structure of foreign news: The presentation of the Congo, Cuba and Cyprus crises in four Norwegian newspapers, Journal of International Peace Research, nr 1, s. 64-91.

Gaziano C. (1995), Forecast 2000: Widening knowledge gaps, Journalism and Mass Communication Quarterly, nr 74, s. 237-264. 
Gaziano C. (2017), Knowledge gap: History and development, [w:] P. Roessler, C.A. Hoffner, L. van Zoonen (red.), The International Encyclopedia of Media Effects, Oxford: Wiley-Blackwell 2017, s. 837-849.

Gerstenfeld P.B., Grant D.R., Chiang Ch. (1995), Hate online: A content analysis of extremists Internet sites, Analysis of Social Issues and Public Policy, nr 3(1), s. 29-44.

Grossman L.K. (1995), The electronic republic: Reshaping democracy in the information age, New York: Viking.

Habermas J. (2007), Strukturalne przeobrażenia sfery publicznej, tłum. W. Lipnik, M. Łukasiewicz, Warszawa: Wydawnictwo Naukowe PWN.

Harcup T. i O'Neill D. (2001), What is news? Galtung and Ruge revisited, Journalism Studies, nr 2(2), s. $261-280$.

Herman E.S., Chomsky N. (1988), Manufacturing consent: The political economy of the mass media, New York: Pantheon.

Hułas M. (2019), Decydować samemu. Sfera publiczna jako „locus” autonomii wedtug Jürgena Habermasa, Lublin: Wydawnictwo KUL.

Hwang Y., Jeong S.-H. (2009), Revisiting the knowledge gap hypothesis: A meta-analysis of thirty-five years of research, Journalism and Mass Communication Quarterly, nr 86, s. 513-532.

Jankowski J.N., van Selm M. (2000), The promise and practice of public debate in cyberspace, [w:] K. Hacker, J. van Dijck (red.), Digital democracy: Issues of theory and practice, London: Sage, s. 149-165.

Johnson M., Paulussen S., Van Aelst P. (2018), Much Ado About Nothing? The low importance of Twitter as a sourcing tool for economic journalists, Digital Journalism, $\mathrm{nr}$ 6(7), s. 869-888.

Kwak N. (1999), Revisiting the knowledge gap hypothesis: Education, motivation, and media use, Communication Research, nr 26, s. 385-413.

Lecheler S., Kruikemeier S. (2016), Re-evaluating journalistic routines in a digital age: A review of research on the use of online sources, New Media \& Society, nr 18(1), s. 156-171.

Lewin K. (1947), Frontiers in group dynamics: II. Channels of group life. Social planning and action research, Human Relations, nr 1, s. 143-153.

Lippmann W. (1997), Public opinion, New York: Free Press Paperbacks.

Mayer-Schönberger V., Ramge T. (2018), Reinventing capitalism in the age of big data, New York: Basic Books.

Murray J., Cammaerts B., Mansell R. (2020), Digital platform policy and regulation: Toward a radical democratic turn, International Journal of Communication, nr 14, s. 135-154.

Negroponte N. (1998), Beyond digital, Wired, nr 6(12), s. 288-289.

Park R.E. (1940), News as a form of knowledge: A Chapter in the Sociology of Knowledge, The American Journal of Sociology, $\mathrm{nr}$ 45(5), s. 669-686.

Pasquale F. (2018), The automated public sphere, [w:] A.R. Sætnan, I. Schneider, N. Green (red.), The politics and policies of big data: Big data, big brother?, New York: Routledge, s. 110-128.

Pavlik J.V. (1994), Citizen access, involvement, and freedom of expression, [w:] F. Williams, J.V. Pavlik (red.), The people's right to know: Media, democracy, and the information highway, Hillsdale, NJ: Erlbaum, s. 139-162.

Peterson S. (1979), Foreign news gatekeepers and criteria of newsworthiness, Journalism Quarterly, nr 56, s. 116-125.

Peterson S. (1981), International news selection by the elite press: A case study, Public Opinion Quarterly, nr 45(2), s. 143-163. 
Rheingold H. (1993), The virtual community, Cambridge: Addison-Wesley.

Ritzer G. (2011), The McDonaldization of society, [w:] G. Ritzer, The McDonaldization of Society 6, Los Angeles-New York-London-New Delhi: Sage, s. 215-239.

Schudson M. (1989), The sociology of news production, Media, Culture and Society, nr 11, s. 263-282.

Schudson M. (2002), The news media as political institutions, Annual Review of Political Science, nr 5(1), s. 249-269.

Splichal S. (1999), Public opinion. Developments and controversies in the twentieth century, Lanham: Rowman \& Littlefield.

Stone G., Hartung B., Jensen D. (1987), Local television news and the good-bad dyad, Journalism Quarterly, nr 64, s. 37-44.

Szwed R. (2009), Proces produkcji informacji: od gatekeepera do public relations, [w:] L. Dyczewski (red.), Jaka informacja?, Warszawa-Lublin: Wydawnictwo KUL, Fundacja „Centrum Europejskie Natolin", s. 53-74.

Szwed R. (2016), Framing of the Ukraine-Russia conflict in online and social media, Riga: NATO StratCom.

Thorsen E., Jackson D. (2018), Seven characteristics defining online news formats: Towards a typology of online news and live blogs, Digital Journalism, nr 6(7), s. 847-868.

Tichenor P.J., Donohue G.A., Olien C.N. (1970), Mass media flow and differential growth in knowledge, Public Opinion Quarterly, nr 34(2), s. 159-170.

Van Dijck J., de Waal M., Poell T. (2018), The platform society: Public values in a connective world, Oxford, UK: Oxford University Press.

Viswanath K., Finnegan J.R., Jr. (1996), The knowledge gap hypothesis: Twenty-five years later, [w:] B.R. Burleson (red.), Communication yearbook 19, Thousand Oaks: Sage, s. 187-227.

Vliegenthart R., Boukes M. (2018), On the Street and / or on Twitter?: The use of "every day" sources in economic news coverage by online and offline outlets August 2018, Digital Journalism, nr 6(7), s. 829-846.

Von Nordheim G., Boczek K., Koppers L. (2018), Sourcing the Sources: An analysis of the use of Twitter and Facebook as a journalistic source over 10 years in The New York Times, The Guardian, and Süddeutsche Zeitung, Digital Journalism, nr 6(7), s. 807-828.

Wahl-Jorgensen K. (2014), Is WikiLeaks challenging the paradigm of journalism? Boundary work and beyond, International Journal of Communication, $\mathrm{nr}$ 8, s. 2581-2592.

Wei L., Hindman D.B. (2011), Does the digital divide matter more? Comparing the effects of new media and old media use on the education-based knowledge gap, Mass Communication and Society, nr 14, s. 216-235.

White D.M. (1950), The "gate keeper": A case study in the selection of news, Journalism and Mass Communication Quarterly, nr 27(4), s. 383-391.

Williams F. (1994), On prospects for citizens' information services, [w:] F. Williams, J.V. Pavlik (red.), The people's right to know: Media, democracy, and the information highway, Hillsdale, New Jork: Erlbaum, s. 3-24.

Williams B.A., Delli Carpinii M.X. (2000), Unchained reaction: The collapse of media gatekeeping and the Clinton-Lewinsky scandal, Journalism, nr 1(1), s. 61-85. 


\title{
KRYZYS INFORMACJI W ZMEDIATYZOWANEJ SFERZE PUBLICZNEJ - OD MEDIÓW TRADYCYJNYCH DO HYBRYDOWYCH PLATFORM KOMUNIKACYJNYCH
}

\begin{abstract}
Streszczenie
Wolny obieg informacji w otwartej i nieskrępowanej sferze publicznej stanowi jeden z fundamentów dobrze funkcjonujących demokracji. Dla ich właściwego funkcjonowania niezbędny jest dostęp do rzetelnych informacji, które - docierając do obywateli - pozwalają im podejmować właściwe decyzje i kontrolować władzę. Analizując proces produkcji informacji w tradycyjnych i nowych mediach, należy uwzględnić wiele czynników: wydawców - właścicieli mediów, reklamodawców - biznes, technologie komunikacyjne, instytucje public relations, a obecnie algorytmy. Ważnym elementem są też konsumenci i prosumenci treści medialnych, którzy w mniej lub bardziej kompetentny sposób starają się uczestniczyć w medialnym biegu informacji. Pojawienie się platform komunikacyjnych redystrybuujących informacje zrewolucjonizowało relacje między elitami, mediami i opinią publiczną. Co ważniejsze, przyczyniło się do dalszego kryzysu sfery publicznej, zaufania i defragmentaryzacji społeczeństw. Zdezorientowani obywatele są bombardowani informacjami, których źródeł nie potrafią ocenić, a dezinformacja, fake newsy i postprawda na trwałe weszły do popularnego słownika, wypierając „niemodną” propagandę i cenzurę. Przedmiotem artykułu będzie analiza aktualnego stanu mediasfery - poprzez pryzmat słabości tradycyjnego dziennikarstwa, niedostatecznych kompetencji odbiorców i niekontrolowanego przepływu informacji sterowanego przez przemysł zarządzania uwagą.
\end{abstract}

Słowa kluczowe: informacja; sfera publiczna; media; luka wiedzy; platformy cyfrowe.

\section{INFORMATION CRISIS IN THE MEDIATISED PUBLIC SPHERE — FROM TRADITIONAL MEDIA TO HYBRID COMMUNICATION PLATFORMS}

\section{Summary}

The free circulation of information in an open and unfettered public sphere is one of the foundations of well-functioning democracies. For theirs proper functioning, access to reliable information is necessary, which - reaching citizens - allows them to make the right decisions and control power. Many factors should be taken into account when analysing the information production process in new and traditional media: publishers-media owners, advertisers-business, communication technologies, public relations institutions, and now algorithms. An important element are also consumers and prosumers of media content, who try to participate in the media flow of information in a more competent or less competent way. The emergence of communication platforms that redistribute information has revolutionized the relationship between the elite, the media, and the public. More importantly, it contributed to the crisis of the public sphere, trust, and defragmentation of societies. Confused citizens are bombarded with information whose sources they cannot assess and disinformation, fake news, and post-truth have permanently entered the popular dictionary, replacing ,unfashionable” propaganda and censorship. The aim of the article will be to analyse the current state of the media sphere through the prism of the weaknesses of traditional journalism, insufficient competences of recipients and uncontrolled flow of information controlled by the attention management industry.

Keywords: information; public sphere; media; digital platforms. 